\title{
Elements of Multiple Intelligences in Teaching and Learning Activities and the Effect on Students' Achievement Based on Gender
}

\author{
Ikhsan Othman \\ Faculty of Education and Human Development, Sultan Idris University of Education, Malaysia
}

\begin{abstract}
This research article discusses the study on the effect of integrating elements of multiple intelligences in teaching and learning activities on students' achievement based on gender. The participants in the study were from a selected Malaysia National Primary School comprised of 47 male and 55 female students. Intervention was done to the participants in the form of teaching and learning activities which integrate elements of multiple intelligences. The effect of the intervention was measured based on the students' achievement in acquiring knowledge of science and science process skills with KS Test and SPS Test respectively. Data were analyzed using MANCOVA with pretest data as covariate. Results of the study revealed that integrating elements of multiple intelligences in teaching and learning activities has significantly no gender bias $\left(\lambda=.960\right.$, at $F_{(2,97)}=2.041, p=$ .135) amongst students in acquiring the knowledge of science and acquiring science process skills. As a whole, the result of this study shows that teaching and learning activities which integrate elements of MI have a positive impact on upgrading students' achievement democratically and has no gender bias amongst student.
\end{abstract}

Keywords: Multiple intelligences; students' achievement; knowledge of science; science process skills; gender bias.

\section{Introduction}

In Malaysia, National Education Philosophy (NEP) is a guide for the implementation of education system. NEP clearly stated that education is a continuous effort towards enhancing potentials of individuals in a holistic and integrated manner in order to create harmonious individuals who are well balanced and equipped intellectually, spiritually and emotionally (Malaysia Ministry of Education, 2006). A well balanced and harmonious individuals are peoples who posses integrated personality and able to enjoy contentment and happiness spiritually. At the same time the person will also posses competencies, feels grateful and ready to accept challenges and competitions as well as willing to make effort to solve and overcome problems. The philosophy has clear intention to be achieved.

For the sake of the mentioned purpose, curriculum in Malaysia education system should undergo a revamp in stages to make it less exam oriented as well as more democratic to students based on gender, race, culture and social status as Malaysia is a multicultural country. In the year 2001 Malaysia Ministry of Education launched a pilot project of implementing MI in national curriculum. Several schools in state of Selangor Darul Ehsan and Perak Darul Ridzuan were involved in the pilot project. However findings from preliminary studies show that teachers were in curiosity with the effect of integrating elements of MI in their classroom teaching and learning process, especially on students' academic achievement (Ikhsan Othman; 2005, 2010). Additionally the findings also show that teachers were in doubtful on technically how to integrate elements of MI in their teaching and learning activities. In light of the preceding discussion this study aims to identify the effect of integrating elements of MI in teaching and learning activities on students' achievement based on gender. The study embarks on teaching and learning process of Year 5 National Primary School Science subject.

\section{Research Questions}

Specifically research questions are as follows:

(a) What is the effect of integrating elements of MI in teaching and learning activities on students' achievement in acquiring knowledge of science (KS) based on gender?

(b) What is the effect of integrating elements of MI in teaching and learning activities on students' achievement in acquiring science process skills (SPS) based on gender?

\section{Research Hypotheses}

Specifically null hypotheses for this study are as follows:

$\mathrm{Ho}(1)$ : There is no significant difference based on gender the effect of integrating elements of MI in teaching and learning activities on students' achievement in acquiring KS. 
Ho(2) : There is no significant difference based on gender the effect of integrating elements of MI in teaching and learning activities on students' achievement in acquiring SPS.

\section{Multiple Intelligences In Curriculum And Instruction: Literature Revisited}

In 1997 a Harvard Psychologist named Howard Gardner suggested an eighth intelligence, namely "naturalist intelligence" to the original list of multiple intelligences (MI) to make the list contains eight intelligences namely linguistic, logical-mathematic, spatial, bodily-kinesthetic, musical, interpersonal, intrapersonal and naturalist.

Before that Gardner in 1983 first mapped the broad range of human abilities by grouping them into seven categories of intelligences and was called as Multiple Intelligence Theory. Gardner suggested that intelligence has more to do with the capacity for solving problems and fashioning product in a context-rich and naturalistic setting. When one has a problem to solve or a project to accomplish, all of intelligences work together in a wellorchestrated and integrated way (Lazear 1999). His book named Frames of Mind was then very popular with the theory. Organizations such as Rockefeller Foundation, Lilly Endowment, Spencer Foundation and MacArthur Foundation took initiative by giving fund to research the theory (Armstrong,1994).

The effort on MI was then broadened and applied in education where schools can integrate a unique blend of the intelligences in curriculum and instruction (Blyte \& Gardner, 1990). School began to integrate MI into their programs. United States of America as well as United Kingdom, Canada and Australia successfully implement the MI theory in their education system (Lefebvre, 2004; McMahon, Rose \& Parks, 2004; Schwert, 2004; Shearer, 2004).

Virtually everyone has the capacity to develop all intelligences to a reasonably high level of performance if given appropriate encouragement, enrichment or instruction. Fortner (2004), Young (2003) and Ozdener \& Ozcoban (2004) through their studies prove that integrating MI in teaching and learning process can improve students' achievements. For the sake of integrating the element of MI in teaching and learning activities teachers can pick and choose in a way suited to their own unique teaching style and congruent with their educational policy (Armstrong , 1994). This study implemented the procedure call Ask Key MI Question by Armstrong (1994) for integrating elements of $\mathrm{MI}$ in the teaching and learning activities. Table 1 is an adaptation of the procedure used.

TABLE 1: MI PLANNING QUESTIONS

(Adapted from Armstrong, T. 1994, Multiple intelligences in the classroom)

\begin{tabular}{|c|c|c|}
\hline & $\begin{array}{c}\text { MULTIPLE } \\
\text { INTELLIGENCES }\end{array}$ & $\begin{array}{c}\text { ASK KEY MI QUESTION FOR INTEGRATING } \\
\text { ELEMENTS OF MI IN TEACHING AND LEARNING } \\
\text { PROCESS }\end{array}$ \\
\hline \multirow{8}{*}{$\begin{array}{c}\text { SPECIFIC } \\
\text { LEARNING } \\
\text { OBJECTIVE } \\
\ldots \ldots \ldots\end{array}$} & Linguistik & How can I use the spoken or written word? \\
\hline & $\begin{array}{l}\text { Logical- } \\
\text { mathematic }\end{array}$ & $\begin{array}{l}\text { How can I bring in numbers, calculations, logic, } \\
\text { classifications, or critical thinking skills? }\end{array}$ \\
\hline & Spatial & $\begin{array}{l}\text { How can I use visual aids, visualization, colour, art or } \\
\text { metaphor? }\end{array}$ \\
\hline & Musical & $\begin{array}{l}\text { How can I bring in music or environmental sound, or set } \\
\text { key points in a rhythmic or melodic framework? }\end{array}$ \\
\hline & Bodily-Kinesthetid & $\begin{array}{l}\text { How can I involve the whole body or use hands-on } \\
\text { experiences? }\end{array}$ \\
\hline & Interpersonal & $\begin{array}{l}\text { How can I engage students in peer sharing, cooperative } \\
\text { learning, or large-group simulation? }\end{array}$ \\
\hline & Intrapersonal & $\begin{array}{l}\text { How can I evoke personal feelings or memories, or give } \\
\text { students choices? }\end{array}$ \\
\hline & Naturalist & $\begin{array}{l}\text { How can I bring the skills of observation, indentification } \\
\text { and classification of the world? }\end{array}$ \\
\hline
\end{tabular}

According to the procedure, the teacher for the subject will first determine the specific learning objective of the selected topic or subtopic. This will be followed by asking questions about the relevant elements of MI to be integrated in the selected learning activities. It is not necessary to integrate all elements of MI in the activities. Instead only the relevant one will be chosen.

\section{Design Of The Study}

The aim of this study is to identify the effect of multiple intelligences in teaching and learning activities on students' achievement in acquiring knowledge of science and science process skills based on gender. The participants for the study were from a selected Malaysia National Primary Schools comprised of 47 male and 55 female in three classrooms. The study just not possible to randomly assign participants to groups as agreement or permission received for the study need to keep students in the existing classrooms. Therefore randomization was avoided due to the availability of intact classrooms in their natural setting without disruption to classrooms learning. 
Intervention was done to the participants in the form of teaching and learning of Year 5 National Primary School Science subject. The intervention was done in a period of eight weeks with the used of lesson plans prepared by the researcher. Prior to the intervention, a pretest was administered and a posttest was also administered at the end of the intervention.

\section{Data Collection and Data Analysis}

The effect of the intervention was measured based on the students' achievement in acquiring KS and achievement in acquiring SPS. KS Test was used to measure students' achievement in acquiring KS. SPS Test was used to measure students' achievement in acquiring SPS. Both tests have high reliability for a classroom test. Both tests also have adequate content validity as the items were formulated based on the learning outcomes for the content coverage of the subject in Year 5 Primary School Science Syllabus. The tests had also been validated by those who are specialist in Year 5 Primary School Science subject.

The independent variable in the study is gender and there are two dependent variables involved in the study. First is students' achievement in acquiring KS and second is students' achievement in acquiring SPS.

Multivariate analysis is suitable to analyze dataset with more than one dependent variable (Hair, Black, Babin, Anderson \& Tatham, 2006). Therefore Multivariate Analysis of Covariance (MANCOVA) was used to analyze the dataset from the pretest and posttest of this study. Scores from pretest are as covariate. Covariate could handle the problems of pre-existing group differences as it reduces the effect by making a compensating adjustment to the posttest scores of the intervention groups (Coakes \& Steed, 2003). The dataset would first be subjected to exploratory data analysis for meeting associated assumptions which include normality and homogeneity of regression slopes to permit the multivariate analysis.

\section{Result}

Results of the study in this report presented according to the research questions and research hypotheses. To illuminate the research questions and to examine the null hypotheses, dataset was analyzed and the findings are summarized in Table 2, Table 3, Table 4 and Table 5. Table 2 shows descriptive statistics of the adjusted mean scores for male students and female students on the achievement in KS test and achievement in SPS Test. Table 3 shows the result of Box's test while Table 4 shows the result of Levene's test to meet the assumptions which include normality and homogeneity of regression slopes. Table 5 shows the result of multivariate test.

TABLE 2: ADJUSTED MEAN SCORES MALE STUDENTS AND FEMALE STUDENTS

\begin{tabular}{|l|l|c|c|c|}
\hline & Gender & $\mathrm{N}$ & Adjusted Mean Scores & SD \\
\hline \multirow{2}{*}{ KS Test } & Male & 47 & $28.53^{\mathrm{a}}$ & .447 \\
\cline { 2 - 5 } & Female & 55 & $29.77^{\mathrm{a}}$ & .411 \\
\hline \multirow{2}{*}{ SPS Test } & Male & 47 & $9.88^{\mathrm{a}}$ & .329 \\
\cline { 2 - 5 } & Female & 55 & $10.04^{\mathrm{a}}$ & .303 \\
\hline
\end{tabular}

a Covariates appearing in the model are evaluated at the following values: Pretest KSTest $=19.4608$, Pretest SPSTest $=3.8137$

\section{TABLE 3: BOX'S TEST OF EQUALITY OF COVARIANCE} MATRICES(A)

\begin{tabular}{|l|r|}
\hline Box's M & 4.00 \\
\hline F & 1.30 \\
\hline df1 & \\
\hline df2 & 951206 \\
\hline Sig. & .27 \\
\hline
\end{tabular}

Tests the null hypothesis that the observed covariance matrices of the dependent variables are equal across groups.

a Design: Intercept+Pretest KSTest+Gender

TABLE 4: LEVENE'S TEST OF EQUALITY OF ERROR VARIANCES(A)

\begin{tabular}{|l|r|r|r|r|}
\hline & \multicolumn{1}{|c|}{ F } & df1 & df2 & \multicolumn{1}{c|}{ Sig. } \\
\hline Pretest KSTest & 1.92 & & 10 & .16 \\
\hline Pretest SPSTest & .03 & & 10 & .86 \\
\hline
\end{tabular}

Tests the null hypothesis that the error variance of the dependent variable is equal across groups. a Design: Intercept+Pretest KSTest+Gender 
TABLE 5: MULTIVARIATE TESTS(B)

\begin{tabular}{|l|l|r|r|r|r|r|r|}
\hline \multicolumn{2}{|l|}{ Effect } & Value & \multicolumn{1}{c}{ F } & Hypothesis df & Error df & $\begin{array}{r}\text { Pig. } \\
\text { Squartial Eta }\end{array}$ \\
\hline Pretest KSTest & $\begin{array}{l}\text { Wilks' Lambda } \\
(\lambda)\end{array}$ & .65 & $25.521(\mathrm{a}$ & 2.00 & 97.00 & .00 & .34 \\
\hline Pretest SPSTest & $\begin{array}{l}\text { Wilks' Lambda } \\
(\lambda)\end{array}$ & .82 & $10.589(\mathrm{a})$ & 2.00 & 97.00 & .00 & .17 \\
\hline Gender & $\begin{array}{l}\text { Wilks' Lambda } \\
(\lambda)\end{array}$ & .96 & $2.041(\mathrm{a}$ & 2.00 & 97.00 & .13. & .04 \\
\hline
\end{tabular}

a Exact statistic

b Design: Intercept+Pretest KSTest+Gender

From Table 2 adjusted mean score of KS Test for male students is 28.53 and adjusted mean score of KS for female students is 29.77. Adjusted mean scores of SPS Test for male students is 9.88 and adjusted mean score of SPS for female students is 10.04. Base on the results of multivariate test in Table 5 the value $\lambda=.960$, at $F_{(2,97)}$ $=2.041, \mathrm{p}=.135$ shows that the diffrence mean score of KS test and mean score of SPS Test between male students and female students is statistically not significant. Therefore the null hypotheses $\operatorname{Ho}(1)$ and $\operatorname{Ho}(2)$ fail to be rejected.

The analysis answers the Researched Questions (a) and Ho(1) that integrating elements of MI in teaching and learning activities has a significant effect on students' achievement in acquiring knowledge of science (KS) but there is no significant difference on the achievement based on gender.

The analysis also answers the Researched Questions (b) and $\operatorname{Ho}(2)$ that integrating elements of MI in teaching and learning activities has a significant effect on students' achievement in acquiring science process skills (SPS) but there is no significant difference on the achievement based on gender.

\section{Discussion}

The finding of this study indicate that integration elements of MI in teaching and learning activities markedly has no significant difference on students achievement based on gender. In other words there is no gender bias amongst students although they have followed lessons with similar content coverage within the same duration. This finding show that teaching and learning process which integrate elements of MI in learning activities has no negative impact on students achievement. The finding is in parallel with the findings from Fortner (2004), Ozdener \& Ozcoban (2004) and Young (2003) that integrating MI in classroom instructions manage to improve student learning process. The finding is also in consistence with the finding of a study in Australia and Indonesia by Third International Mathematics and Science Study (TIMSS) which shows that there is no significant difference on science and mathematics achievement between male students and female students (Adolphe, 2002). This finding can relief teachers' curiosity about the effect of integrating elements of MI in their classroom teaching and learning process. Additionally the findings also illuminate teachers on technically how to integrate elements of MI in their teaching and learning activities.

\section{Conclusion}

From this finding conclusion can be drawn that there is no significant difference in acquiring knowledge of science and acquiring science process skills amongst students who were given instructions which integrate elements of MI base on their gender. In other words teaching and learning activities which integrate elements of MI have a positive impact on upgrading students' achievement democratically and has no gender bias amongst students.

\section{Suggestions}

As an implication for future research, it is recommended that further studies investigating similar impact of integrating elements of MI in teaching learning science be conducted to other grade levels include amongst students in lower and upper secondary school. Further studies investigating similar impact of integrating elements of MI in teaching and learning process should be done for subjects other than Science to acquire broader comparison of the results about the effect of integrating elements of MI in curriculum implementation.

\section{References}

[1] Adolphe, F. S. G. (2002). A cross-national study of classroom environment and attitudes among junior secondary school science students in Australia and in Indonesia. Tesis Doktor Pendidikan Sains. Curtin University of Technology.

Armstrong, T. (1994). Multiple intelligences in the classroom. Virginia: Assoc. for Supervision \& Curriculum Development.

Blyte, T. \& Gardner, H. (1990). A school for all. Educational Leadership Journal. page 33-37.

Coakes, S.J. \& Steed, L.G. (2003). SPSS: Analysis without anguish version 11.0 for windows. Singapore: John Willey \& Sons.

Fortner, S.G. (2004). Examining pedagogical practices through brain-based learning in multiple intelligences theory. Doctor of Education Disertation. Regent University 
[6] Gardner, H. (1983). Frames of Mind. London: Heinemann.

[7] Gardner, H. (2004). Changing minds: The art and science of changing our own and other peoples' minds. Boston: Havard Bussiness School Press.

[8] Hair, J.F., Black, W.C., Babin, B.J., Anderson, R.E. \& Tatham, R.L. (2006). Multivariate data analysis (6th ed.). New Jersey: Pearson Prentice Hall.

[9] Ikhsan Othman (2005). Profil kecerdasan pelbagai murid setelah melalui KBSR. Proceeding National Conference on Skills \& Competencies in Education 2005. Universiti Sains Malaysia. page. $21-27$.

[10] Ikhsan Othman (2010). Aplikasi teori kecerdasan pelbagai dalam kurikulum. Asia Pacific Journal of Educators and Education. Vol. 25. page 21-32.

[11] Lazear, D. (1999). Eight ways of knowing: Teaching for multiple intelligences (3rd ed.). Illinois: Skylight Training \& Publishing Inc.

[12] Lefebvre, R.D. (2004). Multiple intelligences, learning for understanding, and creative assessment: Some pieces to the puzzle of learning. Teacher College Record. Vol. 106(1). page 49-57.

[13] Malaysia Ministry of Education (2006). Laws of Malaysia Act 550: Education Act 1996. Percetakan Nasional Malaysia (Reprint).

[14] Malaysia Ministry of Education (2012). Malaysia Education Blueprint 2013-2025. June $20^{\text {th }} 2013$ from http://www.moe.gov.my/userfiles/file/PPP/Preliminary-Blueprint-Eng.pdf.

[15] McMahon, S.D., Rose, D.S. \& Parks, M. (2004). Multiple intelligences and reading achievement: An examination of the Teele Inventory of multiple intelligences. Journal of Experimental Education. Vol. 73(1). page 41-52.

[16] Ozdener, N. \& Ozcoban, T. (2004). A project based learning model's effectiveness on computer courses and multiple intelligences theory. Educational Science Theory and Practice. Vol. 4(1). page 164-170.

[17] Schwert, A. (2004). Using the theory of multiple intelligences to enhance Science education. Masters Dissertation. Toledo University.

[18] Shearer, B. (2004). Multiple intelligences theory after 20 years. Teacher College Record. Vol. 106(1). hal. 2-6.

[19] Young, B.E. (2003). Multiple intelligences learning and equity in middle school Mathematics education. Doctor Philosophy Thesis. Curtin University Australia. 